\title{
Prelmplantation factor (PIF*) promotes embryotrophic and neuroprotective decidual genes: effect negated by epidermal growth factor
}

\author{
Christina M Duzyj ${ }^{1}$, Michael J Paidas ${ }^{1}$, Lellean Jebailey ${ }^{2}$, Jing Shun Huang ${ }^{3}$ and Eytan R Barnea ${ }^{4,5^{*}}$
}

\begin{abstract}
Background: Intimate embryo-maternal interaction is paramount for pregnancy success post-implantation. The embryo follows a specific developmental timeline starting with neural system, dependent on endogenous and decidual factors. Beyond altered genetics/epigenetics, post-natal diseases may initiate at prenatal/neonatal, post-natal period, or through a continuum. Preimplantation factor (PIF) secreted by viable embryos promotes implantation and trophoblast invasion. Synthetic PIF reverses neuroinflammation in non-pregnant models. PIF targets embryo proteins that protect against oxidative stress and protein misfolding. We report of PIF's embryotrophic role and potential to prevent developmental disorders by regulating uterine milieu at implantation and first trimester.
\end{abstract}

Methods: PIF's effect on human implantation (human endometrial stromal cells (HESC)) and first-trimester decidua cultures (FTDC) was examined, by global gene expression (Affymetrix), disease-biomarkers ranking (GeneGo), neuro-specific genes (Ingenuity) and proteins (mass-spectrometry). PIF co-cultured epidermal growth factor (EGF) in both HESC and FTDC (Affymetrix) was evaluated.

Results: In HESC, PIF promotes neural differentiation and transmission genes (TLX2, EPHA10) while inhibiting retinoic acid receptor gene, which arrests growth. PIF promotes axon guidance and downregulates EGF-dependent neuroregulin signaling. In FTDC, PIF promotes bone morphogenetic protein pathway (SMAD1, 53-fold) and axonal guidance genes (EPH5) while inhibiting PPP2R2C, negative cell-growth regulator, involved in Alzheimer's and amyotrophic lateral sclerosis. In HESC, PIF affects angiotensin via beta-arrestin, transforming growth factor-beta (TGF- $\beta$ ), notch, BMP, and wingless-int (WNT) signaling pathways that promote neurogenesis involved in childhood neurodevelopmental diseases_-autism and also affected epithelial-mesenchymal transition involved in neuromuscular disorders. In FTDC, PIF upregulates neural development and hormone signaling, while downregulating genes protecting against xenobiotic response leading to connective tissue disorders.

In both HESC and FTDC, PIF affects neural development and transmission pathways. In HESC interactome, PIF promotes FUS gene, which controls genome integrity, while in FTDC, PIF upregulates STAT3 critical transcription signal. EGF abolished PIF's effect on HESC, decreasing metalloproteinase and prolactin receptor genes, thereby interfering with decidualization, while in FTDC, EGF co-cultured with PIF reduced ZHX2, gene that regulates neural AFP secretion.

Conclusions: PIF promotes decidual trophic genes and proteins to regulate neural development. By regulating the uterine milieu, PIF may decrease embryo vulnerability to post-natal neurodevelopmental disorders. Examination of PIF-based intervention strategies used during embryogenesis to improve pregnancy prognosis and reduce post-natal vulnerability is clearly in order.

Keywords: Embryogenesis, Neural development, Preimplantation factor (PIF), Neural disease, Uterine environment

\footnotetext{
* Correspondence: Barnea@earlypregnancy.org

${ }^{4}$ Society for the Investigation of Early Pregnancy, 1697 Lark Lane, Cherry Hill, NJ 08003, USA

${ }^{5}$ Biolncept LLC (PIF Proprietary), 1697 Lark Lane, Cherry Hill, NJ 08003, USA

Full list of author information is available at the end of the article
}

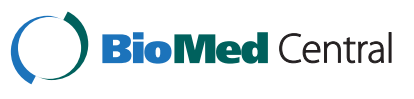

(c) 2014 Duzyj et al.; licensee BioMed Central Ltd. This is an Open Access article distributed under the terms of the Creative Commons Attribution License (http://creativecommons.org/licenses/by/4.0), which permits unrestricted use, distribution, and reproduction in any medium, provided the original work is properly credited. The Creative Commons Public Domain Dedication waiver (http://creativecommons.org/publicdomain/zero/1.0/) applies to the data made available in this article, unless otherwise stated. 


\section{Background}

A rapid and critical period of embryogenesis ensues postembryo hatching and post-implantation; embryogenesis is then completed by 6 weeks post-implantation. During this period, the embryo mainly relies on itself for development, though this paradigm shifts radically towards placenta and mother later in gestation. The intimate contact established by the trophoblast with the maternal decidua enables effective exchange of nutrients and trophic agents. Since trophoblastic cells do not create a true barrier, the embryo benefits from the surrounding uterine milieu.

The earliest structure formed in the embryo postimplantation is the neural plate, with the spinal cord fold fusing by 6 weeks. The genes for proteins such as sonic hedgehog (SHH), wingless-int (WNTs), notch, bone morphogenetic proteins (BMPs), transforming growth factor beta (TGF- $\beta$ ), EPH, and others are implicated in cerebral cortical function and formation [1-3], as chick embryo and rat studies have revealed. Whether all of these regulatory factors are endogenous to embryonic cells, derived from the uterine milieu, or derived from a combination of both sources is not yet fully established. Moreover, it is important to determine whether the embryo itself (by regulating the maternal decidua) is an active participant in directing the flow of trophic compounds or is a passive participant in this process. Finally, embryo-derived secretory products acting on the uterine milieu may provide protection during gestation and possibly prevent disorders that can manifest long after birth. Evidence for such a protective effect derives from experimental observations that trophoblastic cells, and the embryo, effectively inactivate xenobiotics [4-9].

To understand the embryo's role, examining embryospecific compounds' effect on the intrauterine milieu provides crucial information on embryo-induced conditioning involved in successful implantation and ensuing embryogenesis. Preimplantation factor (PIF) is a specific, post-fertilization peptide signal secreted by viable embryos. PIF is expressed both by the embryo/fetus and the placenta and is present in the maternal circulation throughout viable pregnancy [10-12]. PIF exerts four major complementary effects that are essential for pregnancy initiation and maintenance: 1 ) promoting the development of cultured embryos and acting as a rescue factor negating toxic-serum-induced embryo demise [13]; 2) promoting endometrial receptivity by regulating genes that are involved in inflammation, adhesion, and apoptosis and promoting the secretion of immune regulatory ligands and modulation of kinase phosphorylation, which actively condition the uterine environment $[14,15]$; 3) enhancing trophoblastic invasion, which provides effective oxygen and nutrient exchange for the fetus, an effect that is not synergized with epidermal growth factor (EGF) [16]; and 4) regulating systemic immunity to promote embryo tolerance while preserving the maternal ability to fight pathogens/disease and negating NK cell-induced toxicity $[17,18]$.

As recently reported, PIF plays a determining role in the embryo's neural development and neuroprotection by targeting the embryo proteins involved in oxidative stress, protein misfolding, and neural development. Specifically binding to protein-di-isomerase/thioredoxin (PDI/TRX) and heat shock proteins (HSPs) was noted. These major targets share a common binding site for PIF, enabling multi-targeting. In addition, PIF also targets tubulins, backbone of neurons [19]. PIF also upregulates decidual proteins that play a major role in neural function: agrin (a component of the neuromuscular junction), Calpain1 (a cytoskeleton component), NDUFS3 (modulator of oxidative stress), and PPF1BP1 (involved in axon guidance), in human implantation models [14].

PIF reverses advanced brain damage induced by hypoxia and inflammation in newborn rat models [20-22]. In chronic neuro-inflammation models, PIF reverses severe paralysis by reducing oxidative stress and protein misfolding while promoting and facilitating neural repair (by increasing neuron assembly and transmission) via local and systemic effects [23]. In a clinically relevant model for multiple sclerosis, subcutaneous administration of PIF led to reduced brain inflammation and reversal of paralysis. Notably, observations have demonstrated that PIF directly targets microglia, the major immune element within the CNS [24]. In this and other models, the primary PIF targets are insulin degrading enzyme (IDE) and potassium channel Kv1.3b, both of which play a prominent role in neural diseases and are targets for neuroprotective drugs [14].

The aim of the current study is to assess the impact and perform a more complete characterization of PIF's effect on the maternal decidua, both at implantation and during the first trimester, in order to establish its embryotrophic and specifically neurotrophic roles in early gestation. For this, PIF's impact on gene expression was examined in relation to 1 ) genes involved in trophic effects on the embryo with an emphasis on the neural system and 2) genes involved in potentially protecting against development of diseases in childhood and throughout adult life. In addition, 3) PIF's specificity of action was examined by using EGF (a growth factor) as an antagonist. The data generated implies that the embryo, through PIF signaling, can condition the uterine milieu to regulate and mitigate the environmental impact on its own neural development. Thus, PIF, in addition to supporting embryo development, could play a role in decreasing the risk of developing post-natal disorders. 


\section{Methods}

\section{PIF peptide synthesis}

The method was already described [25]. Briefly, synthetic PIF analog (MVRIKPGSANKPSDD) was produced using solid-phase peptide synthesis (Peptide Synthesizer, Applied Biosystems, Foster City, CA, USA) employing 9-fluorenylmethoxycarbonyl (Fmoc) chemistry. Final purification was carried out by reversed-phase high-pressure liquid chromatography, and peptide identity was verified by mass spectrometry as previously described [14].

\section{Endometrial cell cultures}

Yale University School of Medicine review board approval was obtained for this study. Using our previously established cell culture method [14,15], non-pregnant human endometrial stromal cells (HESC) and cells collected from healthy first trimester of pregnancy deciduas were studied. Discarded endometrial tissue from premenopausal women undergoing hysterectomies due to benign indications was used. Decidual specimens from the first trimester were obtained from women undergoing elective termination in weeks 6-12 of normal pregnancy. Endometrial and decidual cells were isolated and re-suspended in Roswell Park Memorial Institute (RPMI)-1640 medium, grown to confluence, and found to be leukocyte free $(<1 \%)$. After reaching confluence, the cells were decidualized using $10^{-8} \mathrm{~mol} / \mathrm{L}$ estradiol and $10^{-7} \mathrm{~mol} / \mathrm{L}$ synthetic progestin analog (R5020) (DuPont/NEN, Boston, MA, USA), in both cases for 7 days. The cells were switched to a serum-free medium containing insulin, transferrin, and selenium (Collaborative Research Inc., Waltham, MA, USA); 5 $\mu \mathrm{mol} / \mathrm{L}$ trace elements (GIBCO, Carlsbad, CA, USA); and $50 \mu \mathrm{g} / \mathrm{mL}$ ascorbic acid (Sigma-Aldrich, St. Louis, MO, USA), and treated for $24 \mathrm{~h}$ with or without synthetic PIF $(100 \mathrm{ng} / \mathrm{mL})$. In other experiments, $50 \mathrm{ng}$ EGF was cultured together with $100 \mathrm{ng} / \mathrm{mL}$ PIF for $24 \mathrm{~h}$ in HESC and first-trimester decidua cultures (FTDC). The tissue culture was collected and frozen at $-80^{\circ} \mathrm{C}$ The samples were tested in triplicate.

\section{Microarray analysis}

Total RNA was extracted from each cell culture. Analysis of HESC or FTDC with and without PIF $100 \mathrm{ng} / \mathrm{mL}(n=3 /$ group) or + - EGF was examined using Affymetrix (Santa Clara, CA, USA) U133 Plus 2.0 Array (>38,500 human genes), followed by fluorescence labeling and hybridization with Fluidics Station 450 and optical scanning with GeneChip Scanner 3000 (Affymetrix) at W. M. Keck Foundation Biotechnology Resource Laboratory, Yale University, New Haven, CT, USA. Raw data were analyzed by GeneSpring software (Agilent, Santa Clara, CA, USA), normalized for inter-chip and intra-chip variations to eliminate falsepositive results.

\section{Statistical analysis: gene pathway (MetaCore)}

Genes that were significantly changed in expression by PIF $(p<0.05)$ using Student $t$ test followed by a greater than twofold change were reported. Further results were divided into upregulated or downregulated lists and underwent new gene pathway analysis. MetaCore from GeneGo Inc., a Thomson Reuters business (Carlsbad, CA, USA), was used to identify and visualize the involvement of differentially expressed genes in specific cellular pathways. Enrichment analysis algorithms across several GeneGo ontologies were used to rank pathways, process, and diseases. To determine possible key regulators that may contribute to PIF-induced changes in gene expression to the human interactome (manually annotated interactions from peer-reviewed published experiments), the interactome tool in the MetaCore platform was used. To further understand the mechanisms and processes represented by the top connected hubs, networks were built using the shortest path algorithm followed by enrichment analysis using the disease and gene ontology processes.

\section{Statistical analysis of neural gene ranking (Ingenuity)}

Pathway analysis was performed using the Ingenuity Systems Inc. (Redwood, CA, USA) software, ranking by greatest number of genes in a given pathway and associated statistical significance.

\section{Mass spectrometry analysis}

HESC protein lysates ( $n=3$ /group) from an independent experiment as compared to those of an mRNA study were homogenized in retinoic acid receptor alpha (RARA) buffer (100 mM Tris $250 \mathrm{mM} \mathrm{NaCl}, 0.1 \%$ Triton $\mathrm{X}-100,0.1 \%$ sodium dodecyl sulfate (SDS)) and assayed for protein concentration. Twenty micrograms of each lysate was loaded in duplicate onto an SDS-poly-acrylamide gel Novex 4\%-12\% (Invitrogen, Carlsbad, CA, USA) followed by electrophoresis. Each lane was excised into 40 equal slices, digested with trypsin, and analyzed by nano-liquid chromatography/mass spectrometry (nano-LC/MS/MS) on an LTQ-Orbitrap $\mathrm{XL}^{\mathrm{m}}$ tandem mass spectrometer (ThermoFisher, San Jose, CA, USA) carried out at NextGen Sciences (Ann Arbor, MI, USA). Data were searched against the Mascot concatenated forward-and-reversed v3.38 International Protein Index (IPI) database (Matrix Science Ltd., London, UK) and collated into non-redundant lists using Scaffold software (Proteome Software Inc., Portland, OR, USA). Using these combined forms of software creating ion identity score, and using the PeptideProphet provide high accuracy by determining true probabilities of proteins identified. Spectral counting was employed for relative quantitation, and a $t$ test was utilized to show significant differences. 


\section{Results}

PIF regulates neurodevelopmental gene expression at embryo implantation phase (HESC) and throughout the first trimester (FTDC)

Neural development initiates shortly post-implantation, and therefore, PIF's effect on pathways that lead to the secretion of neurotrophic factors for the embryo by the decidua was examined (Table 1). The highest ranking gene (13.8-fold increase) is TLX2-a nuclear receptor subfamily 2 group E that binds DNA. This protein plays a major role in anterior brain differentiation and vision development [25]. Also, highly ranking is EPHA10 (9 fold) whose protein encodes a receptor for tyrosine kinase targeted by ephrin-A family members [26]. This protein is important for cell-to-cell communication and neural cell mobility. On the other hand, RARA gene expression decreased ( -9 fold) [27]. This gene encodes a receptor for retinoic acid which is involved in growth arrest.

In FTDC, the major upregulated gene was SMAD1 (53.4-fold increase) (Table 1) [28]. Its encoded protein is

Table 1 Effect of PIF on HESC and FTDC genes involved in specific neural pathways

\begin{tabular}{|c|c|c|c|}
\hline \multicolumn{2}{|c|}{ HESC } & \multicolumn{2}{|c|}{ FTDC } \\
\hline \multicolumn{4}{|l|}{$\overline{T G F \beta}$} \\
\hline TLX2 & 13.8 & SMAD1 & 53.4 \\
\hline CREBBP & -2.2 & SMAD6 & 2.7 \\
\hline SMAD6 & -2.4 & SMAD2 & 2.5 \\
\hline \multirow[t]{2}{*}{ TGFBR1 } & -2.6 & ACVR1C & -3.1 \\
\hline & & INHBC & -4.6 \\
\hline \multicolumn{4}{|l|}{$\mathrm{EPH}$} \\
\hline EPHA10 & 9.0 & EPHA5 & 7.8 \\
\hline CDC42 & 3.7 & RAP1A & 2.3 \\
\hline EPHA5 & 2.4 & EGF & 2.2 \\
\hline ITSN1 & -2.3 & AKT3 & 2.2 \\
\hline PDGFC & -2.6 & STAT3 & -2.1 \\
\hline PTK2 & -3.1 & ANGPT1 & -2.3 \\
\hline EPHA6 & -3.1 & RAC1 & -2.4 \\
\hline AKT2 & -5.6 & & \\
\hline \multicolumn{4}{|l|}{ WNT } \\
\hline MDM2 & 5.0 & SOX17 & 2.5 \\
\hline LEF1 & 2.2 & AKT3 & 2.2 \\
\hline CREBBP & -2.2 & KREMEN1 & -2.3 \\
\hline TLE4 & -2.3 & CSNK2A1 & -2.3 \\
\hline $\mathrm{CDH} 2$ & -2.5 & PPP2R1B & -2.5 \\
\hline TGFBR1 & -2.6 & ACVR1C & -3.1 \\
\hline WNT16 & -3.9 & PPP2R2C & -6.6 \\
\hline AKT2 & -5.6 & & \\
\hline RARA & -9.4 & & \\
\hline
\end{tabular}

TGF $\beta$ signaling protein, a major modulator of the bone morphogenetic protein-highly relevant for embryo neural development [29]. There is also an increase in SMAD6 and SMAD2 (2.7-fold and 2.5-fold, respectively). EPHA5 increased by 7.8-fold; this protein is a receptor tyrosine kinase that binds ephrin-A family ligands, which are highly relevant to neural development, especially axonal guidance and synaptogenesis [30]. On the other hand, PIF downregulates PPP2R2C, which is involved in negative control of cell growth and division [31]. Collectively, this set of data indicates that PIF is involved in pathways that are critical for neural development.

\section{PIF's neurotrophic effects: Ingenuity analysis of neural-related pathways in HESC and FTDC}

PIF also appears to affect several neural-related pathways that could contribute to neurotrophic effects on the embryo. The highest correlation was found with axon guidance signaling followed by neuroregulin, which is involved in EGF signaling; the specific genes involved are listed in Table 2. Effective synaptic transmission is recognized to be critical for effective neural development. The regulatory effect of PIF in this pathway reflects the peptide's significant protective role against altered neural development. The lowest ranking-but still relevant-gene pathway affected by PIF is the oxidative phosphorylation pathway, which is also critical for embryo survival.

Upon analyzing the FTDC data (Table 3), an interesting pattern emerged since the data showed that the highest ranking neural pathways affected by PIF are actually related to adult neurological disorders. Among them are amyloid processing genes that can lead to Alzheimer's disease, amyotrophic lateral sclerosis, and Huntington's chorea. This is followed by effects on neural signaling pathways. PIF's effect on individual genes and their expression in the different pathways is shown in Table 3. This correlation with adult disease implies an evolution in PIF targeting of the maternal milieu with advancing gestation which is different from earlier development phases which appear to be more involved in early childhood diseases.

\section{PIF's effects on HESC and FTDC - pathways and} protection against post-natal disease-MetaCore analysis Since PIF exhibits trophic effects mainly on neural development, it was of interest to further examine the genes involved in embryo development as well, possibly a longterm protective strategy to prevent adverse post-natal disorders. The MetaCore program enabled such analysis. The full description of the role of PIF in multiple cellular signaling pathways is however beyond the scope of this manuscript. Hence, this information is available in detail in Additional file 1 (pages 1-42), and only key findings are referenced herein. For such a comprehensive analysis, the 
Table 2 PIF ranking and effect on neurotrophic gene expression in HESC

\begin{tabular}{|c|c|c|c|c|c|c|c|c|c|c|c|c|c|}
\hline \multicolumn{2}{|c|}{$\begin{array}{l}\text { Axonal guidance signaling } \\
9.20 \mathrm{E}-02\end{array}$} & \multicolumn{2}{|c|}{$\begin{array}{l}\text { Neuregulin signaling } \\
8.70 \mathrm{E}-02\end{array}$} & \multicolumn{2}{|c|}{$\begin{array}{c}\text { Synaptic long-term } \\
\text { potentiation } 7.46 \mathrm{E}-02\end{array}$} & \multicolumn{2}{|c|}{$\begin{array}{l}\text { Amyotrophic lateral } \\
\text { sclerosis signaling } 6.94 \mathrm{E}-02\end{array}$} & \multicolumn{2}{|c|}{$\begin{array}{c}\text { Synaptic long-term } \\
\text { depression } 4.84 \mathrm{E}-02\end{array}$} & \multicolumn{2}{|c|}{$\begin{array}{l}\text { Huntington's disease } \\
\text { signaling } 4.90 \mathrm{E}-02\end{array}$} & \multicolumn{2}{|c|}{$\begin{array}{c}\text { Oxidative phosphorylation } \\
3.47 \mathrm{E}-02\end{array}$} \\
\hline CDC42 & 3.7 & PTEN & 2.6 & CAMK2B & 2 & RAB5A & 3.9 & PRKG1 & -2.5 & CREBBP & -2.1 & ATP6V0D2 & 3.5 \\
\hline EPHA5 & 2.3 & ERBB2IP & -2.2 & CAMK2D & -2.1 & GRIK5 & 2.3 & PRKCB1 & -4.4 & PIK3CA & -2.4 & PPA2 & 3.5 \\
\hline SEMA4C & 2 & PDK1 & -3 & CREBBP & -2.1 & GRIK2 & -2 & GRM1 & -17 & HDAC9 & -3.7 & CYB5A & 3.1 \\
\hline PDGFC & -2.5 & ERBB3 & -3.2 & PRKCB1 & -4.4 & PIK3CA & -2.4 & & & CASP8 & -4.2 & NDUFA10 & 2.1 \\
\hline SEMA6A & -4.5 & PRKCB1 & -4.4 & GRM1 & -17 & $\mathrm{BCL} 2$ & -21 & & & PRKCB1 & -4.4 & NDUFA5 & -2.1 \\
\hline SEMA4D & -6 & AKT2 & -5.6 & & & & & & & AKT2 & -5.6 & & \\
\hline SEMA3D & -10 & & & & & & & & & GRM1 & -17 & & \\
\hline SEMA3C & -11 & & & & & & & & & & & & \\
\hline
\end{tabular}


Table 3 PIF ranking and effect on neurotrophic genes expression in FTDC

\begin{tabular}{|c|c|c|c|c|c|c|c|c|c|c|c|c|c|}
\hline \multicolumn{2}{|c|}{$\begin{array}{l}\text { Amyloid processing } \\
8.33 \mathrm{E}-02\end{array}$} & \multicolumn{2}{|c|}{$\begin{array}{l}\text { Amyotrophic lateral sclerosis } \\
\text { signaling } 8.33 \mathrm{E}-02\end{array}$} & \multicolumn{2}{|c|}{$\begin{array}{l}\text { Huntington's disease } \\
\text { signaling } 7.69 \mathrm{E}-02\end{array}$} & \multicolumn{2}{|c|}{$\begin{array}{l}\text { Synaptic long-term depression } \\
6.45 \mathrm{E}-02\end{array}$} & \multicolumn{2}{|c|}{$\begin{array}{l}\text { Axonal guidance signaling } \\
5.75 \mathrm{E}-02\end{array}$} & \multicolumn{2}{|c|}{$\begin{array}{l}\text { Neurotrophin/TRK } \\
\text { signaling } 4.00 \mathrm{E}-02\end{array}$} & \multicolumn{2}{|c|}{$\begin{array}{l}\text { Neuregulin signaling } \\
1.16 \mathrm{E}-01\end{array}$} \\
\hline AKT3 & 2.1 & GRIK2 & 2.5 & BDNF & 3 & GNA12 & -2 & ARHGEF12 & 9 & BDNF & 3 & NRG1 & 5 \\
\hline CDK5R1 & 2 & RAC1 & -2.4 & AKT3 & 2.1 & PPP2R1B & -2.5 & EPHA5 & 7.8 & CSNK2A1 & -2.3 & PLCG2 & 3.1 \\
\hline \multirow[t]{13}{*}{ CSNK2A1 } & -2.3 & SLC1A2 & -3 & EGF & 2.1 & GUCY1A3 & -4.9 & GLI2 & 6.1 & & & EGF & 2.1 \\
\hline & & РРРЗСА & -9.2 & POLR2J2 & 2 & PPP2R2C & -6.5 & NRP1 & 4.2 & & & AKT3 & 2.1 \\
\hline & & BCL2 & -27 & CDK5R1 & 2 & & & BDNF & 3 & & & CDK5R1 & 2 \\
\hline & & & & TCERG1 & -2 & & & RAP1A & 2.2 & & & ADAM17 & -2 \\
\hline & & & & SNCA & -2 & & & AKT3 & 2.1 & & & PDK1 & -5.2 \\
\hline & & & & CLTC & 3.1 & & & EGF & 2.1 & & & EGFR & -24.5 \\
\hline & & & & $\mathrm{RPH} 3 \mathrm{~A}$ & -3.1 & & & DOCK1 & 2.1 & & & & \\
\hline & & & & EGFR & -24.5 & & & SEMA6D & 2.1 & & & & \\
\hline & & & & & & & & SLIT1 & 2.1 & & & & \\
\hline & & & & & & & & RAC1 & -2.4 & & & & \\
\hline & & & & & & & & $\mathrm{ROBO} 1$ & -2.5 & & & & \\
\hline & & & & & & & & DPYSL5 & -4.6 & & & & \\
\hline & & & & & & & & РРРЗСА & -9.2 & & & & \\
\hline
\end{tabular}


data had to be analyzed as pathway maps, process networks, followed by the specific physiologic processes involved, and finally the disease association, when these processes are perturbed which lead to disease during childhood or in adulthood (Table 4). Data was analyzed as the highest association in each category, with associated statistical significance.

PIF's highest ranking pathway in HESC is the angiotensin signaling via beta-arrestin, which is coupled with neural transmission or nerve impulse associated with nervous system development and, when affected, leads to autism. The second ranking pathway affected by PIF was genes involved in the epithelial-mesenchymal transition (EMT), which is associated with muscle contraction, is needed for neural functionality, and if affected, can lead to child development disorders. Interestingly, PIF was found to have significant associations with pathways relating to mood disorders and stress, TGF $\beta$, WNT, CDK5, and BMP.

Among the significantly upregulated processes for which PIF increased the gene expression more than twofold are (Table 5) angiotensin - via beta arrestin, G-protein signaling RhoA/B, and CDC42, showing that the effects on neurogenesis and immune response are dominant. In contrast, the processes downregulated by PIF are EMT, EGF activation, and axon growth repulsion. The balance among upregulated and downregulated processes implies a dynamic adaptive effect on these pathways.

In FTDC (Table 6), on the other hand, different maps to diseases were identified. PIF's highest ranking pathway was acetaminophen metabolism (i.e., xenobiotics) which relates to reproduction/hormone signaling and, when affected, can lead to autoimmune connective tissue disorders (Table 5). The second ranking pathway was steroid metabolism related to vasculogenesis and, when altered, leads to development of skin disorders. Of note, connective tissue disorders and neoplasms occur mostly in adults. The associated upregulated processes are cell cycle role in 14-3-3, ERK5, and mitosis, and neuronal survival and development. The downregulated processes are xenobiotics related to acetaminophen, 2-napthalamine, benzo (a) pyrene, and steroid metabolism. The emphasis on protection against xenobiotics is critical for PIF's protective role during embryogenesis.

\section{Similarity between PIF's effect on HESC and FTDC}

To document the dynamic gestational age-dependent effect of PIF in early pregnancy, similarities and differences between those critical time periods were examined. Common pathways affected by PIF include muscle contraction and angiotensin signaling via four independent pathways: STATs, ERK, PYK2, and CREB pathways. Neurophysiologic processes affected were melatonin signaling and receptormediated growth axon repulsion. Global processes were transmission of nerve impulses, axonal guidance, and cell adhesion. The similarity between the two time periods with respect to neural development illustrates PIF's continuing role in this critical process.

\section{Interactome analysis of genes affected by PIF}

To better delineate a network of genes associated with PIF activity, an interactome analysis was carried out. This enables us to relate a large number of genes that are linked in a network. The hub enables to define the number of interactions among genes. Table 7 illustrates the leading genes and their interaction. In HESC, FUS was dominant [32]. This gene controls genome integrity and RNA processing and has the highest $(n=68)$ interactions, followed by HIPK2, whose protein is a kinase involved in p53-regulated cellular apoptosis [33].

The FTDC interactions were much more extensive (Table 7). The highest ranking was STAT3 $(n=603)$ [34]. The protein plays a central role in JAK/STAT signaling of several cytokines. The next ranking was CDK1 $(n=$ 389), a kinase that controls cell cycle regulation [35]. Of note, the decidua genes are more connected through two signaling steps than the genes found in HESC, in which three steps are involved.

Table 8 illustrates the top biological processes affected by PIF in HESC. The highly prominent DNA-dependent regulation is required during rapid cellular development. In contrast, the top process in FTDC is the response to chemical stimulus, i.e., protection against adverse environment during embryogenesis. This further substantiated the evolving role of PIF from supporting neural development to protection against xenobiotics.

\section{PIF affects expression of HESC proteins}

Using an independent experiment, the effect of PIF on a number of protein levels was determined by using semiquantitative mass spectrometry (14). To provide a more detailed analysis, we have analyzed, in addition, the effect of PIF on a total of $>1,300$ HESC proteins demonstrating that several of them were affected by PIF (Additional file 2). We found that PIF affected several proteins involved in the control of oxidative stress and protection against abnormal protein synthesis: PDIA3, P4HB (PDI), TXND, PRD6, HSPB1, SDHA, and BAG1. This was clearly in line with the microarray data. In addition, specifically focusing on proteins involved in neural function, the data revealed that PIF affects several additional proteins among them. PPIC is affected in ataxia and in degeneration of Purkinje cells [36]. OCRL is affected in Lowe syndrome oculo-cerebral defects [37]. AP3D1 is involved in budding vesicle transmission to neurons [38]. SLC25A1 and SLC16A1 are proteins involved in mitochondrial transport widely expressed in the central nervous system [39]. LDHA is involved in substania nigra development and is deregulated in glioma tumors [40]. 


\section{Table 4 PIF effect on HESC analyzing maps, processes, disease ranking, and strength of association}

\begin{tabular}{|c|c|c|c|c|c|c|c|}
\hline GeneGo pathway maps & & GeneGo process network & & GO processes & & $\begin{array}{r}\text { GeneGo disea } \\
\text { (by biomarke }\end{array}$ & \\
\hline Name & $p$ value & Name & $p$ value & Name & $p$ value & Name & $p$ value \\
\hline Development_angiotensin signaling via beta-arrestin & 0.001218 & $\begin{array}{l}\text { Neurophysiological } \\
\text { process_transmission of nerve } \\
\text { impulse_ }\end{array}$ & $\begin{array}{l}1.114 \mathrm{E}- \\
06\end{array}$ & $\begin{array}{l}\text { Nervous system } \\
\text { development }\end{array}$ & $1.736 E-16$ & Autistic disorder & $4.026 \mathrm{E}-14$ \\
\hline $\begin{array}{l}\text { Development_regulation of epithelial-to-mesenchymal } \\
\text { transition (EMT) }\end{array}$ & 0.001379 & Muscle contraction & 0.0005106 & $\begin{array}{l}\text { Positive regulation of } \\
\text { biological process }\end{array}$ & $7.282 E-16$ & $\begin{array}{l}\text { Child development } \\
\text { disorders, pervasive }\end{array}$ & 4.887E- 14 \\
\hline G-protein signaling_RhoB regulation pathway & 0.003256 & $\begin{array}{l}\text { Cytoskeleton_regulation of } \\
\text { cytoskeleton rearrangement }\end{array}$ & 0.0009131 & Cell communication & $5.021 E-15$ & Mood disorders & $2.655 E-09$ \\
\hline Cell adhesion_tight junctions & 0.004814 & $\begin{array}{l}\text { Development_neurogenesis: axonal } \\
\text { guidance }\end{array}$ & 0.001197 & Regulation of transport & $9.227 E-15$ & Stress & $2.787 \mathrm{E}-09$ \\
\hline $\begin{array}{l}\text { Muscle contraction_GPCRs in the regulation of smooth } \\
\text { muscle tone }\end{array}$ & 0.005149 & $\begin{array}{l}\text { Reproduction_GnRH signaling } \\
\text { pathway }\end{array}$ & 0.008079 & $\begin{array}{l}\text { Anatomical structure } \\
\text { development }\end{array}$ & 1.207E - 14 & $\begin{array}{l}\text { Mental disorders } \\
\text { diagnosed in childhood }\end{array}$ & $6.579 \mathrm{E}-09$ \\
\hline $\begin{array}{l}\text { Cytoskeleton remodeling_TGF, WNT, and cytoskeletal } \\
\text { remodeling }\end{array}$ & 0.005462 & Cell adhesion_cell junctions & 0.01565 & Regulation of localization & $1.48 \mathrm{E}-14$ & Aortic diseases & $6.6 \mathrm{E}-09$ \\
\hline $\begin{array}{l}\text { Atherosclerosis_role of ZNF202 in regulation of } \\
\text { expression of genes involved in atherosclerosis }\end{array}$ & 0.007208 & $\begin{array}{l}\text { Signal transduction_cholecystokinin } \\
\text { signaling }\end{array}$ & 0.02107 & $\begin{array}{l}\text { Regulation of amine } \\
\text { transport }\end{array}$ & 1.744E - 14 & Aortic aneurysm & $6.801 E-09$ \\
\hline Transcription_CREB pathway & 0.009855 & $\begin{array}{l}\text { Signal transduction_TGF-beta, GDF, } \\
\text { and activin signaling }\end{array}$ & 0.02518 & $\begin{array}{l}\text { Transmission of nerve } \\
\text { impulse }\end{array}$ & $2.15 E-14$ & $\begin{array}{l}\text { Craniomandibular } \\
\text { disorders }\end{array}$ & $1.025 \mathrm{E}-08$ \\
\hline Cell adhesion_role of CDK5 in cell adhesion & 0.01212 & Signal transduction_WNT signaling & 0.02811 & $\begin{array}{l}\text { Positive regulation of } \\
\text { cellular process }\end{array}$ & $2.762 E-14$ & $\begin{array}{l}\text { Temporomandibular } \\
\text { joint disorders }\end{array}$ & $1.025 \mathrm{E}-08$ \\
\hline $\begin{array}{l}\text { Development_TGF-beta-dependent induction of EMT via } \\
\text { MAPK }\end{array}$ & 0.01239 & $\begin{array}{l}\text { Reproduction_gonadotropin } \\
\text { regulation }\end{array}$ & 0.02941 & $\begin{array}{l}\text { Regulation of multicellular } \\
\text { organismal process }\end{array}$ & $3.763 E-14$ & Mandibular diseases & $5.041 \mathrm{E}-08$ \\
\hline
\end{tabular}


Table 5 Summary of enrichment analysis for HESC and FTDC (genes that are expressed more than twofold or decreased twofold) regulating processes following PIF treatment

\begin{tabular}{|c|c|c|c|c|}
\hline \multirow[b]{2}{*}{ Ontology } & \multicolumn{2}{|l|}{ HESC } & \multicolumn{2}{|c|}{ FTDC } \\
\hline & Upregulated processes & Downregulated processes & Upregulated processes & Downregulated processes \\
\hline \multirow[t]{10}{*}{$\begin{array}{l}\text { GeneGo Pathway } \\
\text { Maps }\end{array}$} & G-protein signaling_RhoB regulation pathway & $\begin{array}{l}\text { Development_TGF-beta-dependent } \\
\text { induction of EMT via MAPK }\end{array}$ & $\begin{array}{l}\text { Cell cycle_role of } 14-3-3 \text { proteins in } \\
\text { cell cycle regulation }\end{array}$ & $\begin{array}{l}\text { Androstenedione and testosterone } \\
\text { biosynthesis and metabolism p.2 }\end{array}$ \\
\hline & Development_angiotensin signaling via beta-Arrestin & $\begin{array}{l}\text { Immune response_CD137 signaling in } \\
\text { immune cell }\end{array}$ & Development_EGFR signaling via PIP3 & Acetaminophen metabolism \\
\hline & G-protein signaling_RhoA regulation pathway & $\begin{array}{l}\text { Development_regulation of epithelial-to- } \\
\text { mesenchymal transition (EMT) }\end{array}$ & $\begin{array}{l}\text { Apoptosis and survival_role of CDK5 } \\
\text { in neuronal death and survival }\end{array}$ & $\begin{array}{l}\text { 1-naphthylamine and 1- } \\
\text { nitronaphthalene metabolism }\end{array}$ \\
\hline & Immune response_antiviral actions of Interferons & $\begin{array}{l}\text { Cell adhesion_role of tetraspanins in the } \\
\text { integrin-mediated cell adhesion }\end{array}$ & $\begin{array}{l}\text { Development_neurotrophin family } \\
\text { signaling }\end{array}$ & $\begin{array}{l}\text { Immune response_IL-15 signaling via } \\
\text { JAK-STAT cascade }\end{array}$ \\
\hline & Immune response_IFN alpha/beta signaling pathway & $\begin{array}{l}\text { Development_beta-adrenergic receptors } \\
\text { transactivation of EGFR }\end{array}$ & $\begin{array}{l}\text { Neurophysiological process_receptor- } \\
\text { mediated axon growth repulsion }\end{array}$ & $\begin{array}{l}\text { 2-naphthylamine and 2- } \\
\text { nitronaphthalene metabolism }\end{array}$ \\
\hline & $\begin{array}{l}\text { Development_signaling of beta-adrenergic receptors } \\
\text { via beta-arrestins }\end{array}$ & $\begin{array}{l}\text { Development_gastrin in differentiation of } \\
\text { the gastric mucosa }\end{array}$ & $\begin{array}{l}\text { Role of alpha- } 6 / \text { beta- } 4 \text { integrins in car- } \\
\text { cinoma progression }\end{array}$ & Estradiol metabolism \\
\hline & G-protein signaling_regulation of CDC42 activity & $\begin{array}{l}\text { Neurophysiological process_receptor- } \\
\text { mediated axon growth repulsion }\end{array}$ & Cell cycle_cell cycle (generic schema) & $\begin{array}{l}\text { G-protein signaling_regulation of } R A C 1 \\
\text { activity }\end{array}$ \\
\hline & $\begin{array}{l}\text { Muscle contraction_GPCRs in the regulation of smooth } \\
\text { muscle tone }\end{array}$ & $\begin{array}{l}\text { Transcription_androgen receptor nuclear } \\
\text { signaling }\end{array}$ & $\begin{array}{l}\text { Development_ERK5 in cell } \\
\text { proliferation and neuronal survival }\end{array}$ & $\begin{array}{l}\text { Immune response_IL-15 signaling via } \\
\text { JAK-STAT cascade }\end{array}$ \\
\hline & $\begin{array}{l}\text { Neurophysiological process_EphB receptors in dendritic } \\
\text { spine morphogenesis and synaptogenesis }\end{array}$ & $\begin{array}{l}\text { Regulation of } \\
\text { metabolism_triiodothyronine and } \\
\text { thyroxine signaling }\end{array}$ & Cell cycle_initiation of mitosis & Benzo [a] pyrene metabolism \\
\hline & G-protein signaling_regulation of RAC1 activity & $\begin{array}{l}\text { Cell adhesion_integrin-mediated cell } \\
\text { adhesion and migration }\end{array}$ & $\begin{array}{l}\text { G-protein signaling_K-RAS regulation } \\
\text { pathway }\end{array}$ & $\begin{array}{l}\text { Apoptosis and survival_HTR1A } \\
\text { signaling }\end{array}$ \\
\hline
\end{tabular}


Table 6 PIF effect on FTDC analyzing maps, processes, disease ranking, and strength of association

\begin{tabular}{|c|c|c|c|c|c|c|c|}
\hline \multicolumn{2}{|l|}{ GeneGo pathway maps } & \multicolumn{2}{|l|}{ GeneGo process networks } & \multicolumn{2}{|l|}{ GO processes } & \multicolumn{2}{|c|}{ GeneGo diseases (by biomarker) } \\
\hline Name & $p$ value & Name & $p$ value & Name & $p$ value & Name & $p$ value \\
\hline Acetaminophen metabolism & 0.00001014 & $\begin{array}{l}\text { Reproduction_feeding and } \\
\text { neurohormones signaling }\end{array}$ & 0.0004425 & $\begin{array}{l}\text { Multicellular organismal } \\
\text { process }\end{array}$ & $2.563 E-14$ & $\begin{array}{l}\text { Skin and connective } \\
\text { tissue diseases }\end{array}$ & $1.006 \mathrm{E}-10$ \\
\hline $\begin{array}{l}\text { Androstenedione and testosterone biosynthesis and } \\
\text { metabolism p.2 }\end{array}$ & 0.00003172 & $\begin{array}{l}\text { Development_blood vessel } \\
\text { morphogenesis }\end{array}$ & 0.003215 & $\begin{array}{l}\text { Regulation of biological } \\
\text { quality }\end{array}$ & $9.359 E-14$ & Skin diseases & $1.014 \mathrm{E}-09$ \\
\hline $\begin{array}{l}\text { Cell cycle_role of } 14-3-3 \text { proteins in cell cycle } \\
\text { regulation }\end{array}$ & 0.00003564 & Muscle contraction & 0.003752 & $\begin{array}{l}\text { Positive regulation of } \\
\text { biological process }\end{array}$ & $1.611 E-13$ & $\begin{array}{l}\text { Neoplasms by } \\
\text { histologic type }\end{array}$ & $2.396 \mathrm{E}-09$ \\
\hline $\begin{array}{l}\text { Androstenedione and testosterone biosynthesis and } \\
\text { metabolism p.2/rodent version }\end{array}$ & 0.0000375 & Cell cycle_meiosis & 0.00434 & $\begin{array}{l}\text { Regulation of multicellular } \\
\text { organismal process }\end{array}$ & $3.408 E-13$ & Myoepithelioma & $1.598 \mathrm{E}-08$ \\
\hline Development_EGFR signaling via PIP3 & 0.00004489 & Cell cycle_G2-M & 0.005763 & Regulation of localization & $4.975 E-13$ & $\begin{array}{l}\text { Neoplasms, glandular, } \\
\text { and epithelial }\end{array}$ & $2.089 E-08$ \\
\hline Cell cycle_initiation of mitosis & 0.00006886 & $\begin{array}{l}\text { Development_ossification and } \\
\text { bone remodeling }\end{array}$ & 0.007848 & Regulation of secretion & $8.326 \mathrm{E}-13$ & Capillary leak syndrome & $6.196 \mathrm{E}-08$ \\
\hline Development_prolactin receptor signaling & 0.00007228 & DNA damage_DBS repair & 0.00865 & Intracellular signaling cascade & $1.943 E-12$ & Breast neoplasms & $8.058 \mathrm{E}-08$ \\
\hline $\begin{array}{l}\text { Apoptosis and survival_role of CDK5 in neuronal death } \\
\text { and survival }\end{array}$ & 0.0003167 & $\begin{array}{l}\text { Development_regulation of } \\
\text { angiogenesis }\end{array}$ & 0.01318 & $\begin{array}{l}\text { Cellular calcium ion } \\
\text { homeostasis }\end{array}$ & $2.698 \mathrm{E}-12$ & Breast diseases & $8.287 E-08$ \\
\hline Estradiol metabolism & 0.0003642 & $\begin{array}{l}\text { Reproduction_male sex } \\
\text { differentiation }\end{array}$ & 0.01432 & Calcium ion homeostasis & $4.215 E-12$ & Schizophrenia & $1.035 E-07$ \\
\hline G-protein signaling_regulation of RAC1 activity & 0.0004169 & Translation_regulation of initiation & 0.0149 & $\begin{array}{l}\text { Cellular metal ion } \\
\text { homeostasis }\end{array}$ & $4.501 E-12$ & $\begin{array}{l}\text { Connective tissue } \\
\text { diseases }\end{array}$ & $1.222 \mathrm{E}-07$ \\
\hline
\end{tabular}


Table 7 Interactome analysis of PIF-induced hubs of genes more and less than twofold in both HESC and FTDC as it is related to protein function analysis

\begin{tabular}{|c|c|c|c|c|c|}
\hline \multicolumn{3}{|c|}{ HESC } & \multicolumn{3}{|c|}{ FTDC } \\
\hline HUB & $\begin{array}{l}\text { Number of interactions with } \\
\text { interactome (total hubs }=21,579 \text { ) }\end{array}$ & $\begin{array}{l}\text { Number of interaction with PIF-HESC } \\
\text { genes (total hubs }=363 \text { ) }\end{array}$ & HUB & $\begin{array}{l}\text { Number of interactions with } \\
\text { interactome (total hubs }=21,579 \text { ) }\end{array}$ & $\begin{array}{l}\text { Number of interaction with PIF-FTDC } \\
\text { genes (total hubs }=384 \text { ) }\end{array}$ \\
\hline ATBF1 & 19 & 3 & PEA3 & 239 & 12 \\
\hline NK31 & 37 & 4 & STAT3 & 603 & 26 \\
\hline Plexin A4 & 12 & 3 & c-Rel & 382 & 16 \\
\hline HIPK2 & 60 & 7 & CDK1 & 389 & 22 \\
\hline SYNJ2BP & 37 & 5 & UGT1A6 & 9 & 3 \\
\hline \multirow[t]{2}{*}{ FUS } & 68 & 7 & UGT1A1 & 31 & 5 \\
\hline & & & Beta-fodrin & 65 & 8 \\
\hline
\end{tabular}


Table 8 Top biological process of Interactome Hub networks, associated with statistical significance and major genes involved in the process

\begin{tabular}{|c|c|c|c|c|c|c|c|}
\hline \multicolumn{4}{|c|}{ HESC } & \multicolumn{4}{|c|}{ FTDC } \\
\hline Process & Percentage & $p$ value & Expressed genes & Process & Percentage & $p$ value & $\begin{array}{l}\text { Expressed } \\
\text { genes }\end{array}$ \\
\hline Regulation of transcription, DNA-dependent & 74.07 & $1.216 E-28$ & NKX3-1, SP3, SOX2, STAT3, ZFHX3 & Response to chemical stimulus & 69.84 & $4.365 E-24$ & \\
\hline Regulation of RNA metabolic process & 74.07 & $3.141 E-28$ & & Response to organic substance & 57.14 & $4.814 \mathrm{E}-24$ & $\begin{array}{l}\text { UGT1A1, } \\
\text { STAT3 }\end{array}$ \\
\hline $\begin{array}{l}\text { Regulation of transcription from RNA } \\
\text { polymerase II promoter }\end{array}$ & 59.26 & $4.227 E-28$ & STAT3 & $\begin{array}{l}\text { Positive regulation of biological } \\
\text { process }\end{array}$ & 71.43 & $5.785 E-24$ & \\
\hline Positive regulation of gene expression & 57.41 & $6.061 E-28$ & MDM2 & $\begin{array}{l}\text { Positive regulation of macromolecule } \\
\text { metabolic process }\end{array}$ & 50.79 & $2.78 \mathrm{E}-21$ & \\
\hline Positive regulation of transcription & 55.56 & $4.355 E-27$ & NKX3-1, SOX2, STAT3 & Organ development & 63.49 & $3.189 E-21$ & \\
\hline Transcription & 74.07 & $1.364 E-26$ & $\begin{array}{l}\text { NKX3-1, SP3, SOX2, STAT3, HIPK2, } \\
\text { ZFHX3 }\end{array}$ & Positive regulation of cellular process & 65.08 & $3.603 E-21$ & \\
\hline Regulation of transcription & 79.63 & $2.039 E-26$ & $\begin{array}{l}\text { NKX3-1, SP3, SOX2, STAT3, HIPK2, } \\
\text { ZFHX3 }\end{array}$ & $\begin{array}{l}\text { Positive regulation of cellular metabolic } \\
\text { process }\end{array}$ & 50.79 & $1.333 E-20$ & \\
\hline $\begin{array}{l}\text { Positive regulation of nucleobase, nucleoside, } \\
\text { nucleotide, and nucleic acid metabolic process }\end{array}$ & 55.56 & $1.925 E-25$ & & Positive regulation of gene expression & 42.86 & $4.074 \mathrm{E}-20$ & CDK1 \\
\hline $\begin{array}{l}\text { Positive regulation of transcription, } \\
\text { DNA-dependent }\end{array}$ & 50 & $3.096 \mathrm{E}-25$ & HIPK2 & Positive regulation of metabolic process & 50.79 & $5.766 \mathrm{E}-20$ & \\
\hline Positive regulation of RNA metabolic process & 50 & $3.955 E-25$ & & Response to stimulus & 77.78 & 4.007E - 19 & \\
\hline $\begin{array}{l}\text { Positive regulation of macromolecule } \\
\text { biosynthetic process }\end{array}$ & 55.56 & $4.246 \mathrm{E}-25$ & & System development & 66.67 & $4.06 \mathrm{E}-19$ & \\
\hline $\begin{array}{l}\text { Positive regulation of nitrogen compound } \\
\text { metabolic process }\end{array}$ & 55.56 & $5.851 \mathrm{E}-25$ & & $\begin{array}{l}\text { Positive regulation of transcription, } \\
\text { DNA-dependent }\end{array}$ & 38.1 & $4.184 \mathrm{E}-19$ & TP63, REL \\
\hline
\end{tabular}


Thus, PIF also affects not only genes but also decidual proteins.

\section{Reciprocal negative interaction between PIF and EGF in HESC and FTDC}

EGF is reported to block decidua formation, and PIF was shown to regulate EGF-related pathways, promoting amphiregulin and epiregulin while inhibiting betacellulin [15]. Therefore, whether EGF can affect PIF's action was examined. Addition of EGF abolished PIF's effect on the global genome. Only a limited number of genes $(N=15)$ were affected, mostly of which were downregulated. The EGF treatment-related pathway is shown (Figure 1). The decrease noted in MMP metalloproteinase expression may interfere with decidual function [41]. This is further amplified by the decrease in prolactin receptor (Figure 2), where the ligand is crucial for decidua formation. The most downregulated gene was BMPER, an inhibitor of BMP ( -10 fold) followed by NIF3LBP1 ( -7.4 fold), which binds NIF3 (an amyotrophic lateral sclerosis candidate gene), MCC1 ( -7.4 fold) (a tumor suppressor), and PRLR $(-4.2)$ (a prolactin receptor important for decidua function) [42-46]. The gene polymorphism is associated with multiple sclerosis. The only gene which was increased is Nov (2 fold), which is a negative regulator of cell growth in choriocarcinoma cells [47].
PIF significantly reduces EGF receptor ( -25.6 fold) in FTDC, therefore blocks the ligand's activity [14]. Whether EGF interferes with PIF's action on the decidua was analyzed. The most downregulated gene was ZHX2 (-8.4 fold), which was shown to promote AFP secretion leading to activation in liver cancer [48]. Figure 3 shows that EGF reduced IL8 expression and decreased PDE3A ( -5.6 fold), involved in learning and memory [49]. There was also a decrease in PEG3, which blocks inflammation-induced apoptosis and is a tumor suppressor in glioma cells (-6.3 fold). Interestingly, PIF alone on FTDC negated both PEG3 ( -5 fold) and PDE7B (-5.7 fold) [50,51]. These observations document the negative relationship between PIF, a promoter of decidual function, and EGF, which acts as a pro-proliferative agent with anti-decidual properties.

\section{Discussion}

After hatching but before being protected by the placenta, the embryo is highly vulnerable to maternal adversity. However, the embryo has developed efficient protective mechanisms. It is herein demonstrated that PIF, an embryo-secreted peptide, differentially conditions the maternal uterine environment during implantation and the first trimester. By regulating the uterine milieu, PIF provides crucial embryotrophic support for the neural system, which is of central importance to the early embryo's

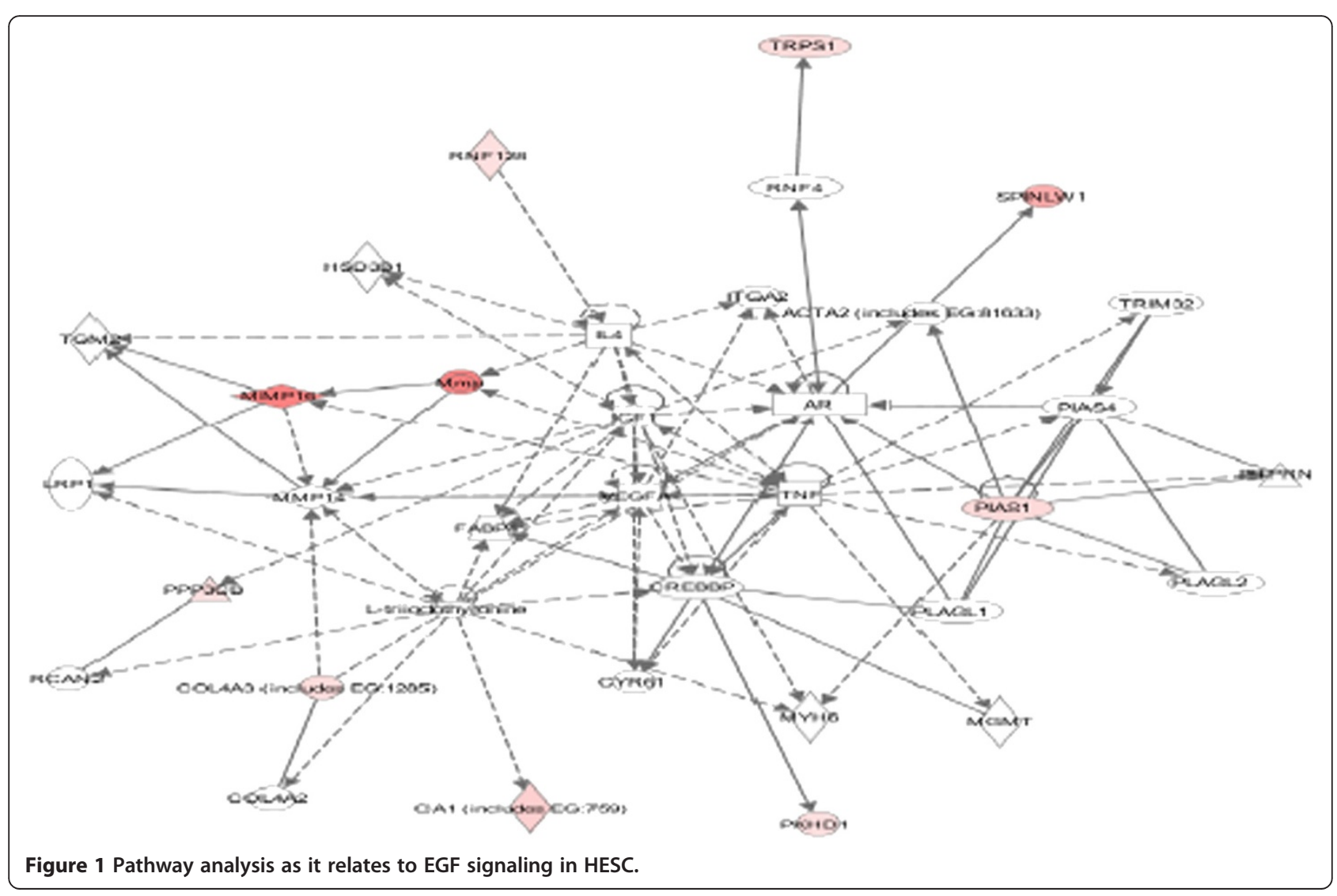




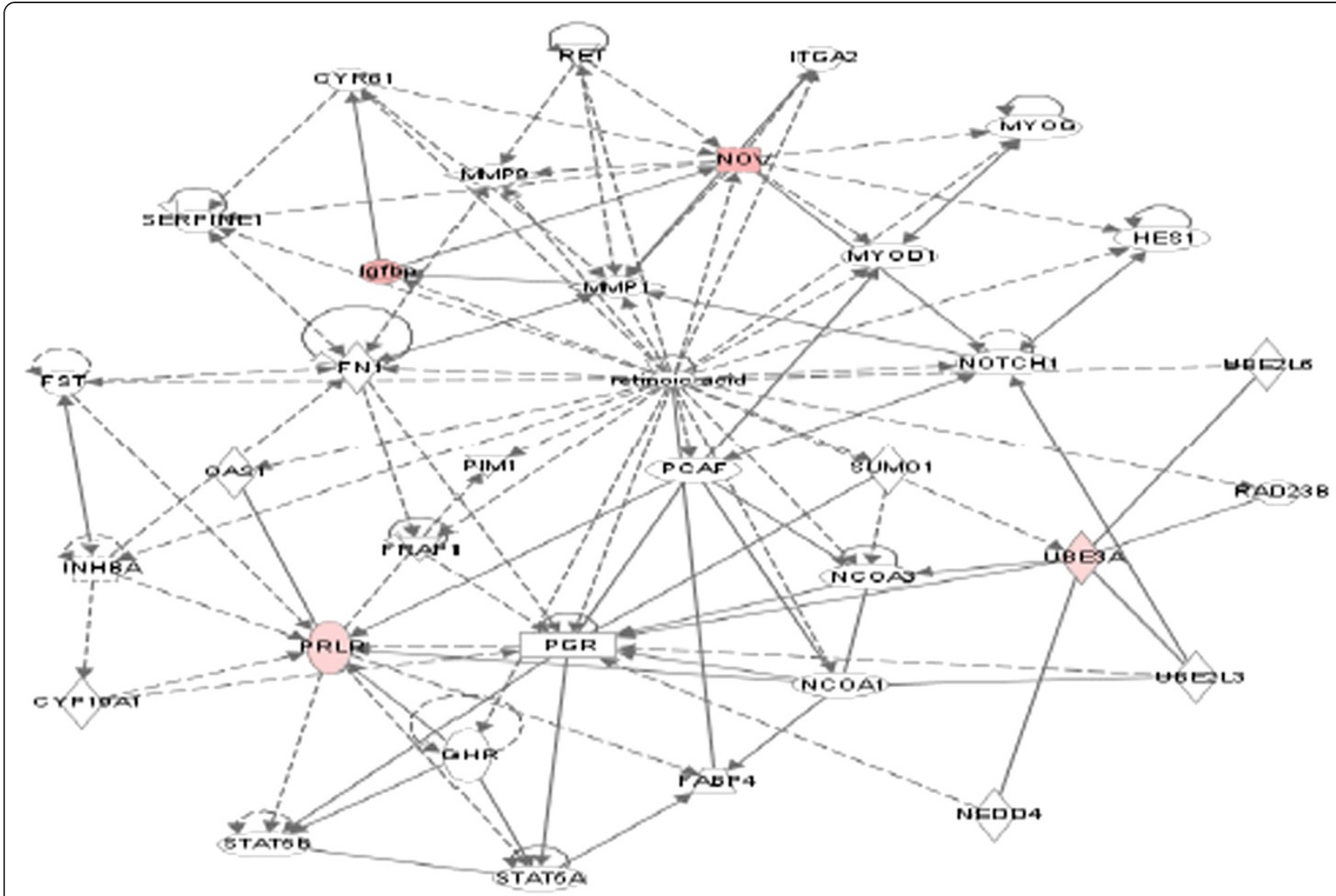

Figure 2 Pathway analysis as it relates to prolactin receptor gene in HESC.

development and has deep consequences throughout early as well as throughout adult life. During implantation, PIF's major effect is exerted on neurotrophic genes that are involved in regulating signaling involved in neurodevelopmental disorders. PIF, in the first trimester decidua during embryogenesis, affects signaling pathways that are involved in protecting against xenobiotic exposure and regulates pathways involved adult neurodegenerative and autoimmune connective tissue disorders. In contrast, EGF, a potent growth factor, is a PIF antagonist and abolishes its protective effects on the decidua. This demonstrates that PIF's embryotrophic and protective effect is dynamic and dependent on the conditioning of the maternal milieu.

Numerous decidual genes related to neural function and development affected by exposure to PIF are herein characterized and analyzed. This complements and expands observations of PIF's effect on genes associated with secreted products and phosphorylated kinases that can aid in embryo development [14,15]. The observation that post-implantation PIF is present in the maternal circulation and is expressed by the placenta creates an intimate link between this embryo/trophoblast-secreted peptide and the maternal uterine environment [11]. The use of two advanced modes of gene analysis (Ingenuity and MetaCore) reveals complex mechanisms involved in PIF's action.

PIF's gene/pathway regulation was examined as it is related to embryotrophic effects. Post-implantation, the neural plate forms via migration of primary cells, with fusion of the neural folds within 30 days post-conception; the upper segment then forms the brain, while the lower segment forms the spinal cord. Several trophic factors are involved in neural formation, including the TGF $\beta$, BMP-2, EPH-1, and WNT-3 pathways [1-3]. Some trophic factors are endogenous to the embryo (which has a very small surface area for synthesis/secretion), while other trophic factors are of decidual origin which has a larger surface area and are likely to be dominant.

PIF upregulates decidual trophic genes, several of which promote neural system development. Specifically, during the implantation period, increases are noted in TLX2 and EPHA10 (a brain trophic agent and an agent that improves neural transmission, respectively). Conversely, PIF lowers RARA expression, preventing growth arrest. This was further emphasized in PIF's neural pathway ranking where the top ranking was in genes promoting axonal guidance and synaptic potentiation. Remarkably, in FTDC, in which the embryo/maternal relationship has already 


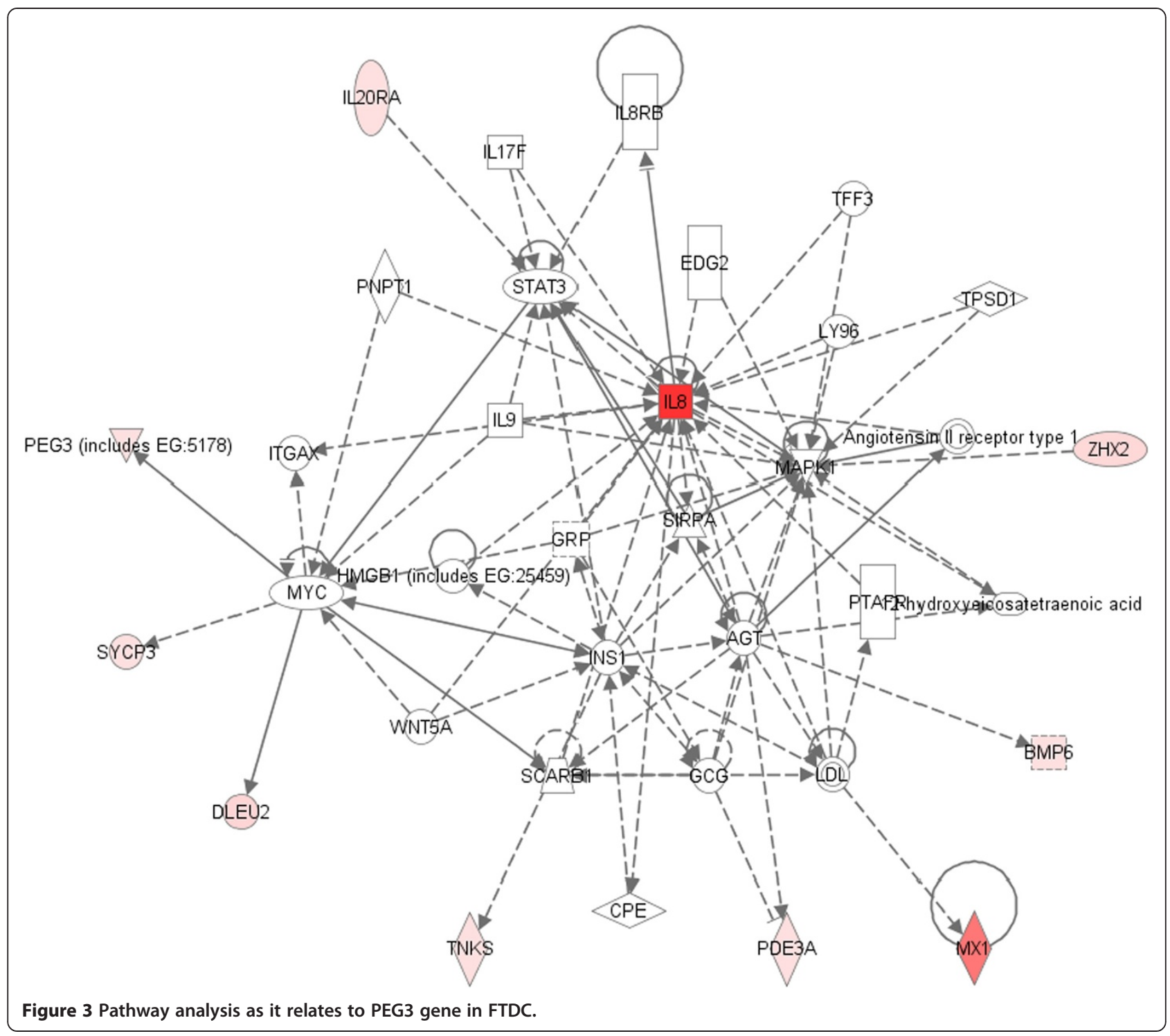

been well established, PIF significantly promotes SMAD1, which is involved in the BMP pathway and is critical for embryo neural development. With regard to pathway ranking in FTDC, PIF's more prominent effects are on genes relating to post-natal diseases since the embryo's neural fold has already been closed at this stage.

The MetaCore program provides a unique insight into gene regulation, pathways, and association with possible diseases. Analyzing in detail PIF's effects on diseaserelated pathways in the two different gestational times identifies a complex picture, since the number of genes affected is very large. This indicates that PIF's effect is robust, especially with respect to the angiotensins (mainly angiotensin II), which serve as brain modulatory factors implicated in stress response and vulnerability to cerebrovascular ischemia and inflammation. Angiotensin receptor blockers may protect neurons [52]. Angiotensin IV and its receptor are implicated in cognitive processing and memory impairment [53]. Specific downstream pathways via CREB and Akt are neural progenitor regulators [54] and targeted by using rapamycin against neonatal hypoxia and ischemia [55]. Additionally, the angiotensin family (1-7) increases neuronal voltage-gated potassium current through nitric oxide pathway [14,56]. Furthermore, viral infections cause, in the prenatal period, activation of the inOS pathway in murine models [57]. We demonstrated that PIF controls the inflammatory response in macrophages by blocking this specific pathway [58]. Therefore, the novel association found between PIF and angiotensin warrants further examination in targeting neurological diseases.

PIF also had a significant effect on genes involved in the EMT [59]. This implies that PIF can affect cells that are involved in enabling transformation of one cell type to 
another, reversibly critical for proper embryo development. On the other hand, under inflammatory conditions, EMT can also be effectively activated, harming the host. The major factors involved are BMP7 and Wilms tumor 1 genes. As a consequence of this regulation, PIF affects genes involved in post-natal neurologic diseases such as autism and later onset neurodegenerative diseases like multiple sclerosis. Thus, altered embryo-maternal communication may increase the susceptibility for such disorders.

Endometrial inflammation is a frequent pathologic environment. When subtle, there may be no clear embryo rejection leading to spontaneous abortion; however, there may still be long-term adverse consequences that can manifest post-partum. PIF may play a role in averting such adverse events. As expected in the decidua, PIF's effect on xenobiotic metabolism and hormonal control are prominent; however, the more subtle effect on neurodevelopmental diseases is still evident, mostly their expression in adult diseases.

Our interactome analysis provided further insight into PIF's gene network, identifying those specifically involved. Interestingly, the linkage between genes was more tightly regulated in the FTDC. Perhaps this is related to the fact that the decidual cells were primary, as compared to HESC, which were steroid-activated stromal cells. Overall, the reciprocal relationship between the embryo through PIF and the maternal decidua appears to play an important role in the earliest stages of development. As the genes affected at implantation and FTDC are different, this is a further confirmation of PIF's selective and targeted effect on the maternal environment.

Further substantiating observations made on PIF regulatory effects on HESC proteins (14), we have examined PIF's effect on the global proteome. PIF affects proteins PDI and HSPs that reduce oxidative stress and protein misfolding. Remarkably, PDI and HSP are also PIF-binding targets (19). Therefore, we further document that PIF not only regulates HESC but also identifies through which proteins such a targeting most likely such effect takes place. Therefore, such data creates an intimate integration between effect and site of action.

The highly ranking neuroregulin pathway in HESC is EGF related. PIF inhibits this pathway by downregulating ERB03, ERBB2IP, and PRKCB-, pro-proliferative genes further amplified by the increase in PTEN, a tumor suppressor. Conversely, EGF completely blocked PIF's effect on both HESC and FTDC, confirming the antagonistic effect of the growth factor. This is expected since EGF promotes decidual cell proliferation and has anti-decidual effects [60]. It is of note that decidual heparin-binding epidermal growth factor-like growth factor (HB-EGF) has distinct properties as compared with EGF [61]. Such inhibitory action indicated also that PIF's effect is dynamic and is dependent on a given decidual environment.
From a clinical perspective, genetic defects and epigenetic modifications are major contributors to postnatal disease. Development of invasive and non-invasive diagnostic tests has led to a significant decrease in the birth of affected children. Despite these advances, in utero identification of more subtle neurodevelopmental disorders is still lacking. In autism, a condition whose incidence continues to rise, recent reports indicate that two complementary brain pathologies co-exist; immune over-activity and reduced neural interaction [62]. Thus, the syndrome may initiate in the prenatal period, as supported by murine models [63]. Consequently, it is important to address how early such defects initiate and whether they are preventable or treatable if identified early. Neural tube defects, and possibly other neurodevelopmental disorders, may also develop during early embryogenesis. Evidently, major neurologic disorders such as anencephaly will be self-limiting or diagnosed and eliminated, whereas more subtle forms might persist. Insight into these processes could move forward the field of neurodevelopment, with significant implications for post-natal life.

\section{Conclusions}

The current study supports the view that the embryo, through PIF, conditions the uterine environment to reduce the impact of adverse maternal environment. In addition to structural imaging, several serum markers (hCG, PAPP-A, estriol, and AFP) can identify neurodevelopmental disorders such as Down's syndrome and neural damage. Recently, metabolites related to oxidative stress were found to be increased in the serum of patients with Down's syndrome [64]. These observations imply that maternal conditioning may play a significant role in regulating embryonic neural development. It is suggested here that PIF could improve such maternal conditioning.

The study is limited since PIF's effects were assessed in culture and therefore cannot directly reflect the in vivo environment. However, the two time-point models used are well established to provide important insight into the biology of early pregnancy. A further strength is the use of two complementary, advanced methods of data analysis which independently confirm the observation that PIF plays a central role in neural control both at implantation and in the first trimester. Finally, the use of EGF in both cell types demonstrated that PIF's effect is specific and can be blocked by the growth factor.

Overall, the current investigation reveals that the embryo, through PIF, conditions the maternal environment, specifically by targeting elements critical for survival (principally, the neural system). Hence, protection observed in both the newborn and the adult may be related to PIF's role in neural development and protection that initiates in 
the earliest stages of pregnancy. Such beneficial maternal conditioning may have long-term ramifications in protecting against childhood and adult neurologic diseases.

\section{Additional files}

\section{Additional file 1: Compare experiments workflow 1.0 data analysis} report. Data describes a detailed comparison and analysis of PIF effect on the HESC and FTDC gene data. This provides visual data of pathways and interactors present in the two time points. This also highlight similarities and differences between the two critical time points of embryo development, implantation, and embryogenesis.

\section{Additional file 2: PIF effect on HESC global proteome in} comparison with vehicle-treated control. HESC were exposed to PIF for $24 \mathrm{~h}$. Subsequently, the cells were collected, washed, and media extracted, and proteins were analyzed by semi-quantitative mass spectrometry. Data was analyzed by comparing PIF treated vs. control, where $p<0.05$ was considered statistically significant.

\section{Competing interests}

This work was supported through an unrestricted grant by Biolncept, LLC (MJP) and National Institutes of Health (grant number 5R01HD056123-02) (SJH). All other authors declare no competing interests.

\section{Authors' contributions}

CMD, MJP, and JSH carried out the experiments and helped in data analysis. $\sqcup$ analyzed the MetaCore program. ERB discovered and developed the PIF technology, helped in data analysis, and wrote the manuscript with CMD, MJP, and LJ. All authors read and approved the final manuscript.

\section{Acknowledgements}

Dr. Graciela Krikun, Roxana Pickering and other members of the Yale University Reproductive Science for technical help. Dr. Richard Jones for the proteomic analysis (NexGen Sciences Inc., MI, USA). We thank Stephanie Zinn and Amy Carter for editorial assistance.

\section{Author details}

${ }^{1}$ Department of Obstetrics, Gynecology and Reproductive Sciences, Yale Women and Children's Center for Blood Disorders, Yale University School of Medicine, 333 Cedar St, P.O. Box 208063, New Haven, CT 06520, USA. ${ }^{2}$ GeneGo Inc., A Thomson Reuters Business, 5901 Priestly Drive Suite 200, Carlsbad, CA 92008, USA. ${ }^{3}$ Department of Obstetrics and Gynecology, Reproductive Biology Unit, The Ohio State University, Columbus, $\mathrm{OH} 43210$, USA. ${ }^{4}$ Society for the Investigation of Early Pregnancy, 1697 Lark Lane, Cherry Hill, NJ 08003, USA. ${ }^{5}$ Biolncept LLC (PIF Proprietary), 1697 Lark Lane, Cherry Hill, NJ 08003, USA.

Received: 11 April 2014 Accepted: 29 August 2014

Published: 11 September 2014

\section{References}

1. Ragsdale CW, Grove EA: Patterning the mammalian cerebral cortex. Curr Opin Neurobiol 2001, 11:50-58.

2. Shimogori T, Banuchi V, Ng HY, Strauss JB, Grove EA: Embryonic signaling centers expressing BMP, WNT and FGF proteins interact to pattern the cerebral cortex. Development 2004, 131:5639-5647.

3. Takebe N, Harris PJ, Warren RQ, Ivy SP: Targeting cancer stem cells by inhibiting Wnt, Notch, and Hedgehog pathways. Nat Rev Clin Oncol 2011, 8:97-106.

4. Shurtz-Swirski R, Simon RJ, Cohen Y, Barnea ER: Human embryo modulates placental function in the first trimester: effects of neural tissues upon chorionic gonadotropin and progesterone secretion. Placenta 1991, 12:521-531.

5. Boadi WY, Urbach J, Barnea ER, Brandes JM, Yannai S: In vitro effect of mercury on aryl hydrocarbon hydroxylase, quinone reductase, catecholamine-0-methyltransferase and glucose-6-phosphate dehydrogenase activities in term human placenta. Pharmacol Toxicol 1991, 68:317-321.
6. Avigdor S, Zakheim D, Barnea ER: Quinone reductase activity in the first trimester placenta: effect of cigarette smoking and polycyclic aromatic hydrocarbons. Reprod Toxicol 1992, 6:363-366.

7. Barnea ER, Avigdor S, Boadi WY, Check JH: Effect of xenobiotics on quinone reductase activity in first trimester explants. Hum Reprod 1993, 8:102-106.

8. Sanyal MK, Li YL, Biggers WJ, Satish J, Barnea ER: Augmentation of polynuclear aromatic hydrocarbon metabolism of human placental tissues of firsttrimester pregnancy by cigarette smoke exposure. Am J Obstet Gynecol 1993, 168:1587-1597.

9. Barnea ER, Shklyar B, Moskowitz A, Barnea JD, Sheth K, Rose FV: Expression of quinone reductase activity in embryonal and adult porcine tissues. Biol Reprod 1995, 52:433-437.

10. Barnea ER: Applying embryo-derived immune tolerance to the treatment of immune disorders. Ann N Y Acad Sci 2007, 1110:602-618.

11. Ramu S, Stamatkin C, Timms L, Ruble M, Roussev RG, Barnea ER: Prelmplantation factor (PIF) detection in maternal circulation in early pregnancy correlates with live birth (bovine model). Reprod Biol Endocrinol 2013, 11:105.

12. Stamatkin CW, Roussev RG, Stout M, Absalon-Medina V, Ramu S, Goodman C, Coulam CB, Gilbert RO, Godke RA, Barnea ER: Prelmplantation Factor (PIF) correlates with early mammalian embryo development-bovine and murine models. Reprod Biol Endocrinol 2011, 9:63.

13. Stamatkin CW, Roussev RG, Stout M, Coulam CB, Triche E, Godke RA, Barnea ER: Preimplantation factor negates embryo toxicity and promotes embryo development in culture. Reprod Biomed Online 2011, 23:517-524.

14. Paidas MJ, Krikun G, Huang SJ, Jones R, Romano M, Annunziato J, Barnea ER: A genomic and proteomic investigation of the impact of preimplantation factor on human decidual cells. Am J Obstet Gynecol 2010, 202:459.e1-459.e8.

15. Barnea ER, Kirk D, Paidas MJ: Preimplantation Factor (PIF*) promoting role in embryo implantation: increases endometrial Integrin- $a v \beta 3$ and amphiregulin and epiregulin while reducing betacellulin expression via MAPK in decidua. Reprod Biol Endocrinol 2012, 10:50.

16. Duzyj CM, Barnea ER, Li M, Huang SJ, Krikun G, Paidas MJ: Preimplantation factor promotes first trimester trophoblast invasion. Am J Obstet Gynecol 2010, 203:402.e1-402.e2.

17. Barnea ER, Kirk D, Ramu S, Rivnay B, Roussev R, Paidas MJ: Prelmplantation Factor (PIF) orchestrates systemic antiinflammatory response by immune cells: effect on peripheral blood mononuclear cells. Am J Obstet Gynecol 2012, 207:313.e1-313.e11.

18. Roussev R, Dons'koi B, Stamatkin C, Ramu S, Chernyshov V, Coulam CB, Barnea ER: Preimplantation factor inhibits circulating natural killer cell cytotoxicity and reduces CD69 expression: implications for recurrent pregnancy loss therapy. Reprod Biomed Online 2012, 26:79-87.

19. Barnea ER, Lubman DM, Liu YH, Absalon-Medina V, Hayrabedyan S, Todorova K, Gilbert RO, Guingab J, Barder T: Insight into Prelmplantation factor (PIF*) mechanism for embryo protection and development: target oxidative stress and protein misfolding (PDI and HSP) through essential RIPK binding site. PLoS One 2014, 9(7):e100263. doi:10.1371/journal.pone.0100263.

20. Mueller M, Zhou J, Yang L, Gao Y, Wu F, Schoeberlein A, Surbek D, Barnea ER, Paidas MJ, Huang Y: Prelmplantation Factor (PIF) promotes neuroprotection by targeting microRNA let-7. Proc Natl Acad Sci US A in press.

21. Muller M, Paidas MJ, Schoeberlein A, Messerli M, Barnea ER, Surbek D: Synthetic Prelmplantation Factor (sPIF) neuroprotective role in intracranial stem cell tranplantation: encephalopathy of prematurity rat model. $Z$ Geburtshilfe Neonato/ 2013, 217:V22_3. doi:10.1055/s-0033-1361330.

22. Muller M, Barnea ER, Schoeberlein A, Barder T, Surbek D, Reinhart U, Paidas MJ: Prelmplantation Factor (PIF*) Exerts Neuroprotective Effects in Severe Encephalopathy of Prematurity (rat model). New Port: New England Perinatal Society (NEPS) meeting; 2014

23. Weiss L, Or R, Jones RC, Amunugama R, JeBailey L, Ramu S, Bernstein SA, Yekhtin Z, Almogi-Hazan O, Shainer R, Reibstein I, Vortmeyer AO, Paidas MJ, Zeira M, Slavin S, Barnea ER: Preimplantation factor (PIF*) reverses neuroinflammation while promoting neural repair in EAE model. J Neurol Sci 2012, 312:146-157.

24. Migliara G, Valentini MAP, Di Sante G, Ria F, Barnea ER: Modulatory PIF* Regulates Post-Infectious EAE in Therapeutic Setting. In SIICA. Florence, Italy: Italian Society of Immunology Annual Meeting; 2014. May.

25. Borghini S, Bachetti T, Fava M, Di Duca M, Cargnin F, Fornasari D, Ravazzolo $R$, Ceccherini I: The TLX2 homeobox gene is a transcriptional target of PHOX2B in neural-crest-derived cells. Biochem J 2006, 395:355-361.

26. Fox BP, Kandpal RP: A paradigm shift in EPH receptor interaction: biological relevance of EPHB6 interaction with EPHA2 and EPHB2 in breast carcinoma cell lines. Cancer Genomics Proteomics 2011, 8:185-193. 
27. Mitchell LE, Murray JC, O'Brien S, Christensen K: Retinoic acid receptor alpha gene variants, multivitamin use, and liver intake as risk factors for oral clefts: a population-based case-control study in Denmark, 1991-1994. Am J Epidemiol 2003, 158:69-76.

28. Chau JF, Jia D, Wang Z, Liu Z, Hu Y, Zhang X, Jia H, Lai KP, Leong WF, Au BJ, Mishina Y, Chen YG, Biondi C, Robertson E, Xie D, Liu H, He L, Wang X, Yu Q, Li B: A crucial role for bone morphogenetic protein-Smad1 signalling in the DNA damage response. Nat Commun 2012, 3:836

29. Matoso E, Melo JB, Ferreira SI, Jardim A, Castelo TM, Weise A, Carreira IM: Insertional translocation leading to a $4 \mathrm{q} 13$ duplication including the EPHA5 gene in two siblings with attention-deficit hyperactivity disorder. Am J Med Genet A 2013, 161A:1923-1928.

30. Backx L, Vermeesch J, Pijkels E, de Ravel T, Seuntjens E, Van Esch H: PPP2R2C, a gene disrupted in autosomal dominant intellectual disability. Eur J Med Genet 2010, 53:239-243.

31. Vance C, Rogelj B, Hortobagyi T, De Vos KJ, Nishimura AL, Sreedharan J, Hu X, Smith B, Ruddy D, Wright P, Ganesalingam J, Williams KL, Tripathi V, Al-Saraj S, Al-Chalabi A, Leigh PN, Blair IP, Nicholson G, de Belleroche J, Gallo JM, Miller CC, Shaw CE: Mutations in FUS, an RNA processing protein, cause familial amyotrophic lateral sclerosis type 6. Science 2009, 323:1208-1211.

32. Tomasini R, Samir AA, Carrier A, Isnardon D, Cecchinelli B, Soddu S, Malissen B, Dagorn JC, lovanna JL, Dusetti NJ: TP53INP1s and homeodomain-interacting protein kinase-2 (HIPK2) are partners in regulating p53 activity. J Biol Chem 2003, 278:37722-37729

33. Cenit MC, Alcina A, Marquez A, Mendoza JL, Diaz-Rubio M, de las Heras $V$, Izquierdo G, Arroyo R, Fernandez O, de la Concha EG, Matesanz F, Urcelay E: STAT3 locus in inflammatory bowel disease and multiple sclerosis susceptibility. Genes Immun 2010, 11:264-268. Bonni A: Activation of FOXO1 by Cdk1 in cycling cells and postmitotic neurons. Science 2008, 319:1665-1668.

35. Lim J, Hao T, Shaw C, Patel AJ, Szabo G, Rual JF, Fisk CJ, Li N, Smolyar A, Hill $D E$, Barabasi AL, Vidal M, Zoghbi HY: A protein-protein interaction network for human inherited ataxias and disorders of Purkinje cell degeneration. Cell 2006, 125:801-814

36. Luo N, West CC, Murga-Zamalloa CA, Sun L, Anderson RM, Wells CD, Weinreb RN, Travers JB, Khanna H, Sun Y: OCRL localizes to the primary cilium: a new role for cilia in Lowe syndrome. Hum Mol Genet 2012, 21:3333-3344.

37. Newell-Litwa K, Chintala S, Jenkins S, Pare JF, McGaha L, Smith Y, Faundez V: Hermansky-Pudlak protein complexes, AP-3 and BLOC-1, differentially regulate presynaptic composition in the striatum and hippocampus. J Neurosci 2010, 30:820-831.

38. Haitina T, Lindblom J, Renstrom T, Fredriksson R: Fourteen novel human members of mitochondrial solute carrier family 25 (SLC25) widely expressed in the central nervous system. Genomics 2006, 88:779-790.

39. LaFlamme B: LDHA deregulation in glioma. Nat Genet 2014, 46:665.

40. Zhang X, Qi C, Lin J: Enhanced expressions of matrix metalloproteinase (MMP)-2 and -9 and vascular endothelial growth factors (VEGF) and increased microvascular density in the endometrial hyperplasia of women with anovulatory dysfunctional uterine bleeding. Fertil Steril 2010, 93:2362-2367.

41. Moser M, Binder O, Wu Y, Aitsebaomo J, Ren R, Bode C, Bautch VL, Conlon FL, Patterson C: BMPER, a novel endothelial cell precursor-derived protein, antagonizes bone morphogenetic protein signaling and endothelial cell differentiation. Mol Cell Biol 2003, 23:5664-5679.

42. Tascou S, Kang TW, Trappe R, Engel W, Burfeind P: Identification and characterization of NIF3L1 BP1, a novel cytoplasmic interaction partner of the NIF3L1 protein. Biochem Biophys Res Commun 2003, 309:440-448.

43. Akiyama H, Fujisawa N, Tashiro Y, Takanabe N, Sugiyama A, Tashiro F: The role of transcriptional corepressor Nif311 in early stage of neural differentiation via cooperation with Trip15/CSN2. J Biol Chem 2003, 278:10752-10762.

44. Arnaud C, Sebbagh M, Nola S, Audebert S, Bidaut G, Hermant A, Gayet O, Dusetti NJ, Ollendorff V, Santoni MJ, Borg JP, Lecine P: MCC, a new interacting protein for Scrib, is required for cell migration in epithelial cells. FEBS Lett 2009, 583:2326-2332.

45. Mellai M, Giordano M, D’Alfonso S, Marchini M, Scorza R, Giovanna Danieli M, Leone M, Ferro I, Liquori M, Trojano M, Ballerini C, Massacesi L, Cannoni S, Bomprezzi R, Momigliano-Richiardi P: Prolactin and prolactin receptor gene polymorphisms in multiple sclerosis and systemic lupus erythematosus. Hum Immunol 2003, 64:274-284.

46. Gellhaus A, Dong X, Propson S, Maass K, Klein-Hitpass L, Kibschull M, Traub O, Willecke K, Perbal B, Lye SJ, Winterhager E: Connexin43 interacts with NOV: a possible mechanism for negative regulation of cell growth in choriocarcinoma cells. J Biol Chem 2004, 279:36931-36942.

47. Shen H, Luan F, Liu H, Gao L, Liang X, Zhang L, Sun W, Ma C: ZHX2 is a repressor of alpha-fetoprotein expression in human hepatoma cell lines. J Cell Mol Med 2008, 12:2772-2780.

48. Sutor B, Mantell K, Bacher B: Evidence for the activity of five adenosine$3^{\prime}, 5^{\prime}$-monophosphate-degrading phosphodiesterase isozymes in the adult rat neocortex. Neurosci Lett 1998, 252:57-60

49. Johnson MD, Wu X, Aithmitti N, Morrison RS: Peg3/Pw1 is a mediator between p53 and Bax in DNA damage-induced neuronal death. $J$ Biol Chem 2002, 277:23000-23007.

50. Ikeda M, Tomita Y, Mouri A, Koga M, Okochi T, Yoshimura R, Yamanouchi Y, Kinoshita Y, Hashimoto R, Williams HJ, Takeda M, Nakamura J, Nabeshima T, Owen MJ, O'Donovan MC, Honda H, Arinami T, Ozaki N, Iwata N: Identification of novel candidate genes for treatment response to risperidone and susceptibility for schizophrenia: integrated analysis among pharmacogenomics, mouse expression, and genetic case-control association approaches. Biol Psychiatry 2010, 67:263-269.

51. Saavedra JM, Sanchez-Lemus E, Benicky J: Blockade of brain angiotensin II AT1 receptors ameliorates stress, anxiety, brain inflammation and ischemia: therapeutic implications. Psychoneuroendocrinology 2011, 36:1-18.

52. Olson ML, Cero IJ: Intrahippocampal norleucine (1)-angiotensin IV mitigates scopolamine-induced spatial working memory deficits. Peptides 2010, 31:2209-2215.

53. Peltier J, O'Neill A, Schaffer DV: PI3K/Akt and CREB regulate adult neural hippocampal progenitor proliferation and differentiation. Dev Neurobiol 2007, 67:1348-1361.

54. Carloni S, Girelli S, Scopa C, Buonocore G, Longini M, Balduini W: Activation of autophagy and Akt/CREB signaling play an equivalent role in the neuroprotective effect of rapamycin in neonatal hypoxia-ischemia. Autophagy 2010, 6:366-377.

55. Yang RF, Yin JX, Li YL, Zimmerman MC, Schultz HD: Angiotensin-(1-7) increases neuronal potassium current via a nitric oxide-dependent mechanism. Am J Physiol Cell Physiol 2011, 300:C58-C64.

56. Fatemi SH, Cuadra AE, El-Fakahany EE, Sidwell RW, Thuras P: Prenatal viral infection causes alterations in nNOS expression in developing mouse brains. Neuroreport 2000, 11:1493-1496.

57. Azar Y, Shainer R, Almogi-Hazan O, Bringer R, Compton SR, Paidas MJ, Barnea ER, Or R: Prelmplantation factor reduces graft-versus-host disease by regulating immune response and lowering oxidative stress (murine model). Biol Blood Marrow Transplant 2013, 19:519-528.

58. Almogi-Hazan O, Shainer R, Barnea ER, Or R: The role of nitric oxide toxicity and oxidative stress in graft vs host disease. In Oxidative Stress: Causes, Role in Diseases and Biological Effects. Edited by Croft C. New York: Nova Science Publishers, Inc; 2014:199-213.

59. Zeisberg M, Hanai J, Sugimoto H, Mammoto T, Charytan D, Strutz F, Kallur R: BMP-7 counteracts TGF-beta1-induced epithelial-to-mesenchymal transition and reverses chronic renal injury. Nat Med 2003, 9:964-968.

60. Sakamoto T, Tanaka T, Umesaki N, Ogita S: Epidermal growth factor inhibits 8-Br-cAMP-induced decidualization of human endometrial stromal cells. Horm Res 2000, 53:294-299.

61. Di Simone N, Di Nicuolo F, Castellani R, Veglia M, Tersigni C, Silano M, Tritarelli A, Scambia G, Marana R: Low-molecular-weight heparins induce decidual heparin-binding epidermal growth factor-like growth factor expression and promote survival of decidual cells undergoing apoptosis. Fertil Steril 2012, 97:169-177.e161.

62. Onore C, Careaga M, Ashwood P: The role of immune dysfunction in the pathophysiology of autism. Brain Behav Immun 2012, 26:383-392.

63. Patterson PH: Immune involvement in schizophrenia and autism: etiology, pathology and animal models. Behav Brain Res 2009, 204:313-321.

64. Bahado-Singh RO, Akolekar R, Mandal R, Dong E, Xia J, Kruger M, Wishart DS, Nicolaides K: Metabolomic analysis for first-trimester Down syndrome prediction. Am J Obstet Gynecol 2013, 208:371.e1-371.e8.

doi:10.1186/1866-1955-6-36

Cite this article as: Duzyj et al:: Prelmplantation factor (PIF*) promotes embryotrophic and neuroprotective decidual genes: effect negated by epidermal growth factor. Journal of Neurodevelopmental Disorders 2014 6:36. 